\title{
The Journal of \\ Thoracic and \\ Cardiovascular \\ Surgery
}

\section{Copyright Transfer and Author Declaration Statement}

\section{Each author must sign this form.}

I (we), the undersigned author(s), transfer all copyright ownership of the manuscript entitled:

to The American Association for Thoracic Surgery, in the event the work is published. I (we) warrant that the article is original work without fabrication, fraud, or plagiarism; does not infringe on any copyright or other proprietary right of any third party; is not under consideration by another publication; and has not been previously published. I (we) also warrant that I (we) have made an important scientific contribution to the study and am thoroughly familiar with the primary data and that I (we) have read the complete manuscript and understand that if the paper or part of the paper is found to be faulty or fraudulent, I (we) share the responsibility.

The corresponding author must be named:

(name)

(signature)

Each author's name must be typed underneath the signature.

Date: 